\title{
Foreign capital flows and economic growth in East Asian countries.
}

\begin{abstract}
This paper provides a quantitative assessment of the effect of various types of capital flow on the growth process of the East Asian countries, including China. The empirical analysis was based on dynamic panel data and we found; first, that domestic savings contribute positively to long-term economic growth. Second, we confirmed that FDI is growth enhancing and that its impact is felt both in the short and long run. Additionally, FDI influence on growth is much higher than domestic savings. Third, short-term capital inflow has adverse effect on the long-term as well as short-term growth prospects and it appears to be sensitive to long-term capital inflows. Fourth, long-term debt has positive effect on growth but its effect does somewhat disappear in the long-term. By and large, the observed positive contribution of FDI in the growth process of East Asian economies is a robust finding. From policy perspective, the evidence convincingly suggests that countries that are successful in attracting FDI can finance more investments and grow faster than those that deter FDI. (c) 2005 Elsevier Inc. All rights reserved.
\end{abstract}

Keyword: Economic growth; Foreign direct investment; Short-term debt 